Orlova, L.Y. (2020). Possible and probable models of formation of a civil society in modern Russia. Past and present in the philosophy of social development. European Scientific e-Journal, 2 (2), 50-62. Hlučín-Bobrovníky: "Anisiia Tomanek" OSVČ.

Орлова, А.Я. (2020). Возможные и вероятные модели формирования гражАанского общества в современной России. Past and present in the philosophy of social development. European Scientific e-Journal, 2 (2), 50-62. Hlučín-Bobrovníky: “Anisiia Tomanek” OSVČ.

DOI: $10.47451 /$ pol2020-09-001

The paper will be published in Crossref, ICI Copernicus, Academic Resource Index ResearchBib, J-Gate, ISI International Scientific Indexing, Zenodo, OpenAIRE, BASE, LORY, LUASA, ADL, eLibrary, and WebArchive databases.

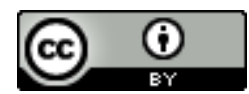

Lyubov Y. Orlova, Full Professor, Doctor of Social Sciences, Peter's Academy of Arts and Sciences

(St. Petersburg), Vice-President of the regional Non-Profit Foundation of the Supporting of St. Petersburg Science, Culture and Sports. St. Petersburg, Russia.

\title{
Possible and probable models of formation of a civil society in modern Russia
}

Abstract: The author considers three possible and probable models of civil society formation in modern Russia, based on a philosophical understanding of the meaning of these categories. The opportunity is an objective reality of becoming subject, as expressed in the conditions for its occurrence; the probability is a concept describing a quantitative measure of the possibility of occurrence of some event under certain conditions. In article political, economic, administrative, society cultural resources of possible formation of various models of a civil society in modern Russia are analyzed. The author concludes that during the periods when Russia was turning towards civil society, its formation was mainly based on the domestic model. Its distinctive feature is rightly considered to be the construction of civil society 'from above' by the state. Their awareness of the need to rely on the capabilities of civil society is the key to the development of the latter.

Keywords: formation models, modern Russian civil society, society and cultural resources, civil society formation.

Аюбовь Яковцевна ОрАова, профессор, Аоктор социологических наук, Академия искусств и наук им Петра Великого, Вице-президент регионального фонда подАержки науки, культуры и спорта. Санкт-Петербург, Россия.

\section{Возможные и вероятные модели формирования гражАанского общества в современной России}

Аннотащия: Автор рассматривает три возможные и вероятные модели формирования гражАанского общества в современной России, основанные на философском понимании значения этих категорий. Возможность - это объективная реальность становления субъектом, выраженная в условиях ее возникновения; вероятность - это понятие, описывающее количественную меру возможности наступления некоторого события при определенных условиях. В статье анализируются политические, экономические, административные, культурные ресурсы общества возможного формирования различных моделей гражданского общества в современной России. Автор приходит к выводу, что в периоды разворота России в сторону гражАанского общества его формирование в основном базировалось на отечественной модели. Его отмичительной чертой по праву считается построение государством гражАанского общщества 
«сверху». Осознание ими необходимости полагаться на возможности гражданского общества явАяется залогом его развития.

Keywords: модели формирования гражАанского общества в современной России, культурные ресурсы формирования гражАанского общества в современной России.

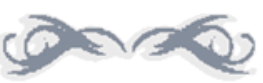

\section{Introduction}

In this article, we consider three possible and probable models of civil society formation in modern Russia, based on a philosophical understanding of the meaning of these categories. The opportunity is an objective reality of becoming subject, as expressed in the conditions for its occurrence; the probability is a concept describing a quantitative measure of the possibility of occurrence of some event under certain conditions (Pbilosopbical Encyclopedia, 1983).

\section{Formation of Russian civil society based on the Western model}

The western model of civil society has historically developed before other national models of civil society including the Russian model. Ancient Greek society is considered the cradle of civil society. Polis democracy includes institutions and mechanisms for the functioning of civil society. Ancient Greek society of two periods - Royal and Republican - can also be considered a reference in the formation of civil society. The Middle Ages fall out of the mainstream of civil society. However, starting from the Renaissance and Modern times, the idea of civil society was becoming popular again. The endless struggle between the secular and spiritual authorities, between civil and theological concepts of politics by the beginning of the 17th century was resolved in favor of the first ones (Buychike \&olikov, 2010).

A feature of the formation of the Western European model of civil society is the regulation of the entire range of social and political relations and the organization of the legal space based on the constitution [1]. Modern constitutions have emerged from the differentiation of society and the state, which made it necessary to create a political organization that would support a consensus between them taking into account changing conditions and the balance of power (Medushevsky, 1994).

In this respect, the great French revolution, which adopted the Declaration of the Rights of Man and of the Citizen in 1789, is a great credit. In fact, the 17 articles of the Declaration set out the basic principles of interaction between the state and civil society, e.g., article 3 declares that the source of sovereign power is the nation. No institution or individual can have power that does not come explicitly from the nation. It also states that all citizens have the right to participate through their representatives in the creation of the Law. All citizens are equal before it and, therefore, have equal access to all posts, public offices and occupations according to their abilities and without any other differences, except those that are due to their virtues (Tumanov, 1989).

In historical retrospect, the great role that France played in the progressive development of law and the creation of modern democratic state and legal structures, is particularly clearly visible contrasting with the demand to 'replace the rule of people with the rule of law' with the 'old regime' of absolutism. 
Western civil society has been developing almost without long interruptions for more than four centuries. During this time, a lot of historical experience has been accumulated: civil society institutions, forms and mechanisms of civil initiative have developed. The social structure of civil society, which also includes independent subjects of economic and political life-citizens - in the legal field, has been formed.

The long period of civil society functioning in Western European states is a strong argument to transfer their experience to Russian sphere. Another argument in favor of building a civil society in Russia based on the western model is its effectiveness. Indeed, many social and economic problems are being solved in western states, where civil society was established several centuries ago. However, it is clearly incorrect to compare Russia and Western European states. Everything is incompatible: the geopolitical situation, territory, climate, national mentality, legal awareness of citizens.

The general methodological situation is well known when conducting a comparative analysis - it is possible to compare comparable values.

The above does not mean that there can be no borrowing from the western model of civil society to form civil society in Russia. First of all, we are talking about transferring a number of powers of central state bodies to regions and municipalities. The real development of local selfgovernment in western states makes it possible to develop civil initiative and civic responsibility.

To do this, municipalities have the appropriate powers, their own budget, and support for citizens. Their budget includes municipal schools and the municipal police, which are accountable to the relevant public councils. The most effective forms of direct democracy at the municipal level, such as citizens' gatherings and referendums, contribute to the development of civil initiatives. An example of the development of forms of direct democracy is Switzerland, where all national problems and issues of concern to the cantons are resolved in referendums that are legislative in nature. It seems that Russian society is potentially ready for such a form of democracy, especially since there is some historical experience to hold gatherings, councils, and Veche. In modern conditions, the issue of legislative consolidation of decisions, taken at referendums of various levels and simplification of the procedure for their conduct, is overdue.

Civil society assumes control over the activities of state bodies. The forms and methods of such control are developed by western civil society and may well be borrowed by domestic civil society. Thus, the parliamentary control allows to control the actions of the executive power by means of deputy requests and deputy investigations. This control is most fully exercised in parliamentary republics. The implementation of this practice in Russia - the presidential republic - is very difficult, although it is provided for by law.

Western civil society has accumulated a lot of experience in resolving socio-political conflicts with the authorities. This does not mean that the number of conflicts here is less than in Russia. For the most part, the above-mentioned circumstances occur in the case of the emergence and resolution of social conflicts in states where civil society has been formed according to the western model. Most citizens of Western European states feel that they are equal subjects of social interaction. Based on this social attitude, they are set up for a dialogue with the authorities when resolving conflicts. 
It is necessary to turn to the most well-established definition of social conflict as a form of relations between potential subjects of social interaction, whose motivation is determined by opposing values and norms, interests and needs.

According to R. Darendorff's theory of conflict, a conflict can arise in any organization where there are managers and managed people at all. The resolution of the conflict aims at the redistribution of power and authority. According to Darendorff, three factors are important for their successful resolution:

- recognition of different points of view;

- $\quad$ high organization of the conflicting parties;

- and the existence of rules of the game.

Any civil society develops in a certain social and cultural environment that represents a set of legal and moral norms, legal awareness of citizens, national mentality, traditions and customs. The social and cultural environment of Western European states was formed in antiquity and based on Roman law, which were fundamentally developed legal norms with the priority of individual rights.

Legal nihilism is not typical of Western European civil society in general. It is characterized by compliance with the triad in practice: law - legal awareness - law enforcement. The implementation of this triad makes it possible not only to resolve social conflicts without much upheaval but also to gain public consensus on socially significant reforms. No matter how harsh, stupid, absurd, or unjust the law may be, it must be respected and strictly observed: "The law is harsh, but it is the law".

It should be noted that as one of the principles of the western model of civil society, this triad allows many of its institutions to function. For example, the institution of property can be successfully protected and developed if each owner is sure that the legal framework guarantees him in practice the right of ownership. Even a significant legal framework does not guarantee strict compliance with the law. It is not by chance, e.g., the strictness of domestic laws is compensated by the non-necessity of their implementation, has fixed in the belief of the legal consciousness of Russian citizens

Law enforcement practices that are adequate to the adopted laws, make civil society institutions and mechanisms more effective, and, on the contrary, if it contradicts the laws, then civil society acquires the features of imitation. This relationship is also important when electing institutions of state power, dividing the various branches of government through a system of checks and balances, and regulating any public relations.

So, the western model of civil society has proved its effectiveness for most European states over several centuries of its existence. However, in the course of our political and historical analysis, we should give an answer to the question "What extent can this model be applied to the formation of civil society in Russia to?". What extent it can solve the social and economic problems of modern Russia to? One of them is the problem to implement individual rights. Will the institutions of the western model of civil society, transferred to the Russian soil, be able to resist threats to the exercise of individual rights? We believe that these threats can be eliminated only if a strong state authority is functioning.

Historically, the central government in Russia has all the necessary powers and resources for this. However, as already noted, the nascent civil society has limited resources. Hence, it is 
the system undeveloped and very limited in its capabilities and resources. At the same time, when implementing the western model of civil society, we should get municipal bodies that are able to solve a wide range of social and economic issues.

A serious political problem in modern Russia is the lack of control of state power over civil society. The control mechanisms that operate in western civil society, are naturally imitative in Russian one. Another institution of western civil society - the referendum, which allows you to accumulate, express public opinion, and then translate it into appropriate legislative decisions is practically absent in modern Russian social and political practice. There are no necessary conditions for its implementation: the results of referendums are not legally fixed, their organizational implementation is extremely difficult and, as a rule, meets the resistance of state bodies. Therefore, there is no tradition to hold referendums in Russia, so they are held very rarely and do not have a significant impact on political processes.

It is particularly important to emphasize the fundamentally different nature of the social and cultural environments, in which western and Russian civil societies are formed. First of all, we note the rationality of thinking of the majority of citizens, which permeates the entire political life of Western European civil society: electoral behavior, behavior during referendums, attitude to the current state power. On the contrary, for the Russian social and cultural environment, rationalism is inherent to a much lesser extent. The Russian mentality is characterized by such features as: collectivism, conciliarity, charisma. The legal consciousness of citizens is based not only on legal norms but also on moral ones. In their behavior, citizens are often guided by such moral norms as justice, mercy, and conciliarity.

With the help of Russian national culture and mentality, people interpret the work of civil society institutions and social relations in different ways, see the world through different 'value prisms', and, consequently, treat and adapt to social reality in different ways, too. In modern Russian society, the conformism of a significant part of the population is conditioned by the presence of an authoritarian political regime that uses the national mentality and moral values to interpret social and political events in its own interests.

Thus, building a domestic civil society based on the patterns of the western model is hardly possible. At the same time, those elements of the civil society's western model that do not contradict the Russian social and cultural environment, can be borrowed in the formation of the Russian civil society. First of all, these are institutions of private property, elections of state authorities and municipal self-government.

\section{Simulation model of civil society in Russia}

Imitation of activities, socio-economic and political processes by state authorities is a wellknown fact in historical practice. This imitation is inherent in all political regimes and all types of political culture.

Imitation of civil society in Russia has an objective basis. First, Russian civil society has proved its effectiveness over long historical periods and become a model for its reproduction. Second, the process of civil society forming in Russia is very slow, and there are setbacks. Therefore, the Russian government cannot ignore the formation of civil society. However, the practice of the post-Soviet period shows that it is not interested in real progress of this process. Hence, it is possible to form a model of imitation civil society in Russia. 
Then we should take a closer look at what exactly this can manifest itself in. It is necessary to start with the principles that underlie any civil society, such as electability, turnover, and control of state bodies at all levels.

The laws regulating the entire electoral process of both executive and legislative bodies at the federal and regional levels are adopted in Russia. These are laws on elections of the President of the Russian Federation, the deputies of the State Duma, heads of federal subjects, and legislative assemblies of federal subjects. They guarantee equal rights and political competition for candidates. However, even at the registration stage, candidates find themselves in unequal conditions. For example, in order to be a registered candidate for the position of region head, a person needs to pass the 'municipal filter', i.e., collect the necessary number of signatures of municipal deputies. It is extremely difficult for opposition candidates to do this.

At the stage of the PR campaign for elections, there is almost no competition between candidates, because candidates from the government have many times more airtime to promote their program. In violation of the law, they usually do not go on vacation during elections and use their official position to promote their program.

The next most important principle of civil society is the turnover of state bodies and officials, which is also imitative.

The control of state institutions and officials over civil society is decorative. One of the effective mechanisms for such control could be parliamentary control, control of the media. However, this practice is clearly imitative and permissive. Deputy requests, provided for by the legislation, would be able also to act as an effective mechanism, but they remain a declaration to a large extent.

The institutions of Russian civil society, primarily legislative bodies at all levels, are also mostly imitative in nature. Their dependence on the executive bodies is a well-known fact, and it violates the democratic principle of separation of powers.

It is important to emphasize that civil society should create conditions and mechanisms to manifest civil initiative. There are no such channels in modern Russia. In practice, it is impossible to hold referendums on the most important social and economic reforms.

In the absence of legal channels for civil initiative, lobbying became widespread in modern Russia. The content of lobbying as a social practice depends on the level of economic, political and social development of a country, as well as on the level of civil society institutions in them, the nature and forms of interaction between the state and society, the state and social groups, and ultimately, the state and the individual as the bearer of certain social interests.

The state, being the largest owner today, is also the largest entrepreneur exerting, by its nature, a specific influence on the development of economic and political activity of members of society.

No business entity has such specific advantages as the state. Moreover, it is the state that determines the parameters of the Russian market, prepares laws, and, in fact, exercises its monopoly right to assign and distribute the gross national product without control.

Monopolism has become one of the main obstacles in the development of civil society in Russia and the source of the growing contradiction between the interests of the economically and politically active population of the country, and the interests of monopolies. 
In such a situation, lobbying takes on the features of a latent process, in fact, it is a corrupt communication. Today, a significant part of economic entities associate corruption with lobbying perceiving them as an established business practice. This factor indicates that a significant part of the business community is not psychologically ready to use the mechanisms of civil society in its work.

How much time can a simulation model of civil society be saved in Russia? The answer to this question depends on the researcher's position. There is a point of view that with the departure from the political arena of the current political regime, the imitation of civil society in Russia will also end. Russia will enter the global trajectory of human civilization once again and move in the 'rut' of civil society formation. This position is typical for adherents of the formation of Russian civil society according to the western model.

The common denominator of all these arguments is the hypothesis that ultimately Russian civil society will be built on the patterns of the western model. At the same time, the entire national historical experience is ignored, and the responsibility for the current state of civil society in Russia is assigned to the ruling political class, which is not interested in its development.

This point of view seems to take into account only one factor that is certainly present: the disinterest of the current political regime in the development of civil society. At the same time, the socio-cultural environment and national mentality remain outside the field of analysis. Just they have a significant impact on the formation of the national civil society.

\section{Formation of Russian civil society}

Ask ourselves: why should an alternative domestic model of civil society be proposed for consideration? As for the western model of civil society, it is obvious that this model does not fit well into the context of Russian civilization. It is, first of all, because the development of western civil society takes place in a completely different social and cultural environment. In addition, the formation of civil society in Russia has its own historical and political limitations, which leaves a unique imprint on the nature of its formation. The necessary resources for the development of civil society in Russia also differ significantly from the resources for the development of western civil society.

The Theory of Catch-up Development in relation to the formation of civil society in Russia according to the western model does not stand up to criticism either [2]. It is possible to catch up with a stable state, rather than a western civil society that changes over time. Therefore, the goal set is not achievable in advance. This raises another question: is it necessary to copy western civil society in its modern form? The unrestrained expansion of civil rights, which leads western societies to anarchy, terrorism and the erosion of all the moral foundations developed over the centuries, should hardly be perceived by Russian society. In addition, the specific results of juvenile justice, which on the one hand, allow state bodies to unjustifiably interfere in the lives of families, and on the other hand, sharply restrict the right of families themselves to raise children.

It seems that the answer to this question is obvious to those who are engaged in propaganda and promotion of the western model of civil society in Russia. All possible risks for Russia and Russian civil society should be considered and weighed. 
It is also impossible to follow the simulation model of civil society development indefinitely. It quickly exhausts its possibilities, and its negative side becomes more and more obvious. The most destructive thing in this case may be the disillusionment of the population in civil society and the assertion of the belief that civil society is impossible in Russia, in the public consciousness.

So, it becomes clear that the Russian society needs to present its own domestic model of civil society. Whatever model of civil society we consider, the key issue in this analysis is the relationship between society and the state. It is impossible to understand these relations without analyzing the origins of the nature of the state and society starting with Kievan Rus. In the interests of our argument, we should emphasize that in Rus, and then in Russia, we meet with a unique situation after the capture of Byzantium - the situation of the Christian spiritual and aesthetic ideal, which is the basis of a huge power. Kievan Rus and Russia are a theocracy in which God illuminates and limits the power of the Grand Prince, the Sovereign. When talking about the Orthodox Symphony, about the Church's anointing to the Kingdom, it is often forgotten that God's blessing on power is precisely a restriction of this power, and not a deification of it as such, at all. The Tsar (Grand Prince) is responsible for his people before God - this is the difference between the Russian Orthodox state and eastern despotism (the Tsar as a living 'God') or western absolutism (the king as the appearance of God) (Karin, 2003).

Orthodox Rus and Russia are a state where power begins not "from below" (democracy) or "from the side" (plutocracy) but from above, i.e., from God. The First Rome - pagan - deified itself in the person of Caesar and fell under the blow of barbarians and internal decay. The Second Rome - Orthodox Byzantium - in spite of its proclaimed ideal of symphonies practically separated the priesthood and the Kingdom, agreed with the Catholics (the Union of Florence in 1439, Bulla Unionis Graecorum) and fell under the blows of the Muslims 14 years later.

Moscow, as the third Rome, had a colossal task to unite the temple, the throne and the people into one whole. The solution to this problem involved endowing the national leader with charismatic features, and the people's mentality with recognition of their God-chosen nature.

Thus, a certain archetype of the relationship between state power and society has historically developed. Power is limited not only by laws but God's blessing, which implies its actions on the basis of moral principles. In turn, the people endow the government with charisma agreeing voluntarily to transfer their rights and freedoms to it. In a certain sense, we can say that there is a Russian social contract between the government and society. Historically, it has proved very tenacious and is being implemented despite the change of forms of government and political regimes.

In modern conditions, the social contract between the government and society is based on the promises of the government to provide citizens with security and social justice. Society, in turn, is ready by default to restrict its political rights. At the same time, it should be understood that such a contract can be prolonged only if both sides comply with it, which is unlikely. There are too many factors, both internal and external, that can change this balance.

Despite the historical consensus between the government and society, it is hardly legitimate to say that power is built exclusively from above. The history of Russia provides examples of building power from below. For examples, at one time, the Novgorod Veche, i.e., the institute of people's democracy was the core of the Ancient Russian civil society of the period from the 11th to the 14th 
centuries. In a sense, even during the period of Moscow State, this role was performed by Zemstvo councils. However, during the period of the Russian Empire, when absolutism was established, this tradition was interrupted. There is no need to talk about its renewal during the Soviet period. Representative authorities were decorative in nature.

In modern Russia, all conditions are legally created to form representative authorities at all levels. However, it is obvious that the content of their activities does not meet the challenges they face. The reason for this situation is seen, first of all, in the obvious skew of real power in the direction of the executive bodies of the state.

Practically today in Russia, only executive bodies of state power are engaged in solving urgent social and economic problems of the population. Civil society institutions either do not exist or are formally established without the necessary resources to act them. As they develop, there will be a redistribution of powers between them and state authorities. However, the latter will still remain not above the society but within it engaged in purely state functions.

Now we should focus on non-state institutions of Russian civil society. There are also significant differences in comparison with its western counterpart. Any civil society is characterized by the presence of a large number of non-governmental organizations that express and defend the interests of a social group, accumulate civil initiative to solve public problems. These are political parties, public organizations, foundations, and associations.

Based on the political and historical analysis, we can consider non-governmental organizations that are directly involved in political life, and therefore, in the formation of civil society. In this series, the most important significance is a difference from the political parties of western states. For a number of reasons, political parties in modern Russia are imitative in nature. Their analysis is given in the previous presentation. The place of political parties is to some extent occupied by so-called influence groups that lobby for decision-making in both legislative and representative bodies of state power. The fundamental difference between them is in the difference of political parties, and groups of influence express and defend strictly narrow corporate interests.

Modern Russian society is extremely 'atomized' for many reasons. Social, demographic, and professional groups are poorly aware of their interests and not sufficiently consolidated. Therefore, the social base of political parties is very vague. To some extent, it is determined during political elections, but it remains 'mosaic' in general.

The situation is even more complicated with the ideology, on which these political parties operate. Direct copying of the ideologies of western states' political parties is an option that has already been played out. The consolidation of western civil society along the lines of 'liberalism' and 'social democracy' is a thing of the past. Here the watershed is based on other criteria, in particular, in the United States, it was designated as the interests of supporters of the global transnational economy. Under these conditions, the state forms political parties from above and determines the vector of their development.

Thus, in modern conditions, Russian political parties are not structures of civil society despite their large number and well-developed legal framework to function. In principle, the position on the role of political parties in the formation of civil society in Russia can change only if they really express the interests of structured groups of the population and bring their representatives to power in a competitive struggle. 
The structures of domestic civil society cannot function normally without appropriate mechanisms. If legal mechanisms are fixed in the legal field and other mechanisms (sociopolitical and socio-economic) can be used on this basis, then social and psychological mechanisms can work based on the mentality only. Social and political mechanisms are common to any civil society. However, the social and psychological mechanisms of Russian civil society have their own differences. First of all, they are determined by the national mentality.

Social and psychological mechanisms are based on such a trait as paternalism, i.e., high expectations of citizens in solving their problems by the state and, as a result, inability and unwillingness to solve them independently. Such a feature of the national mentality as charisma is closely related to paternalism, i.e., giving power, first of all to the first persons of the state, infallibility, foresight of the development of society, which removes from citizens personal responsibility for the fate of the country. This has a negative impact on self-government and self-organization of citizens. Paternalism and charisma, as part of the national identity, have a historical projection that makes them stable, passed down from generation to generation.

To change this situation, the state should consistently transfer some of its functions to local self-government bodies. At the same time, the transfer of functions and powers should be accompanied by the transfer of the appropriate resources necessary for their implementation.

\section{Conclusion}

Summing up the above, we can state that during the periods when Russia was turning towards civil society, its formation was mainly based on the domestic model. Its distinctive feature is rightly considered to be the construction of civil society 'from above' by the state. Their awareness of the need to rely on the capabilities of civil society is the key to the development of the latter.

Almost throughout the 18th century, Russia continued the policy of expanding the privileges of the nobility. Thus, under Anna Ioannovna, estates became almost private property of the nobles. By decree of 1736, the landlords were given judicial and political power. They determined the measure of peasants' punishment for escaping. Under Elizabeth Petrovna, landlords became, in effect, the government's agents for overseeing their serfs. In 1760, they were granted the right to send peasants to Siberia for settlement with their credit for recruits, and even to hard labor by decree of 1765 under Catherine the Second. The state granted landowners the right to personal labor and the labor of serfs in exchange for the obligation to pay taxes for them. Landowners were satisfied with this, they were able to trade peasants as a living commodity, sometimes without stopping before the fact to destruct peasant families (Kamensky, 1992).

Under these conditions, the peasants had no choice except to rely on the 'Tsar-Father'. And despite the fact that the situation with the abolition of serfdom were not changing for centuries, faith in a just sovereign did not weaken. It was no accident that a popular proverb was born during the period of the Moscow state: "Tsar is good, but the boyars are bad". This proverb has proved to be extremely stable, since it reflects the deep archetype of national consciousness, and is used in an allegorical sense in modern conditions.

The abolition of serfdom in Russia in 1861 and the subsequent bourgeois-democratic reforms (1861-1870) that ended feudalism in Russia and gave a powerful incentive to the 
formation of civil society, however, did not significantly affect the mentality of the majority of the population. At the same time, a rather thin layer of citizens, who were determined to solve their problems independently, began to form.

The Soviet period of Russian history also did not significantly change the mentality of the majority of the population, since it could not overcome the political and economic alienation of citizens. The slogan of the Bolsheviks, with which they carried out the October revolution Land to the peasants, factories to the workers, power to the Soviets! - remained the declaration. However, paternalism still dominated the public consciousness.

The post-Soviet period of Russian history, which initially gave hope to change the situation, also showed its failure in the 1990s. Civic consciousness was failed to awaken. The archetype of charisma proved to be extremely tenacious, not allowing us to consider the activities of civil servants including top officials as hired by society as a result of elections and other democratic procedures. The majority of Russian fellow citizens have still pinned their hopes on a charismatic leader who can mobilize society to solve key problems.

\section{References:}

Buychik, A.G., Golikov, A.K. (2016). Civilizational space of Italy: economy, political institutions, state and personality in philosophical, political and legal thought. The Ancient World, the Middle Ages, the Renaissance and Enlightenment. 2nd ed. St. Petersburg: Kultinformpress. (in Russian)

Kazin, A.L. (2003). Russian beauty. The foundations of a national aestheticism. St. Petersburg: Russian Institute of Art History; SPbSUF\&T. (in Russian)

Kamensky, A.B. (1992). Under the shadow of Catherine. St. Petersburg: Lenizdat. (in Russian)

Medushevsky, A.N. (1994). What is imaginary constitutionalism? Socis, 2, 71-86. (in Russian)

Tumanov, V.A. (1989). Introductory article in the book of Republic of France. Constitution and Legislative Acts. Moscow: Progress. (in Russian)

Philosophical Encyclopedia (1983). Moscow: Soviet Encyclopedia. (in Russian)

\section{Notes:}

[1] The exception is the United Kingdom, where there is no constitution. However, the political and legal space is organized there through a system of laws and legislative acts in a way that ensures the normal functioning of civil society.

[2] The Catch-up Development Model assumes that Russia has lagged behind Western Europe in social and economic development, and is doomed to continuously catch up with it (following the Western European model) including in the formation of civil society. 